\title{
Rapid Assessment of Buildings Affected by Earthquake: Case Study in Pidie Jaya, Aceh, Indonesia
}

\author{
Aldrin Febriansyah", ${ }^{1, *}$ Rianto $^{2}$, Ari Kusuma Wardana², Ekha Rifki Fauzi ${ }^{3}$ \\ ${ }^{1}$ Department of Architecture, Faculty of Science and Technology, Universitas PGRI Yogyakarta, 55182, Yogyakarta, Indonesia \\ ${ }^{2}$ Department of Informatics, Faculty of Science and Technology, Universitas PGRI Yogyakarta, 55182, Yogyakarta, Indonesia \\ ${ }^{3}$ Department of Electromedical Engineering Technology, Faculty of Science and Technology, Universitas PGRI Yogyakarta, 55182, \\ Yogyakarta, Indonesia
}

Received July 13, 2020; Revised November 16, 2020; Accepted November 29, 2020

\section{Cite This Paper in the following Citation Styles}

(a): [1] Aldrin Febriansyah, Rianto, Ari Kusuma Wardana, Ekha Rifki Fauzi, "Rapid Assessment of Buildings Affected by Earthquake: Case Study in Pidie Jaya, Aceh, Indonesia," Civil Engineering and Architecture, Vol. 8, No. 6, pp. 1217 1224, 2020. DOI: 10.13189/cea.2020.080606.

(b): Aldrin Febriansyah, Rianto, Ari Kusuma Wardana, Ekha Rifki Fauzi (2020). Rapid Assessment of Buildings Affected by Earthquake: Case Study in Pidie Jaya, Aceh, Indonesia. Civil Engineering and Architecture, 8(6), 1217 - 1224. DOI: 10.13189/cea.2020.080606.

Copyright $\odot 2020$ by authors, all rights reserved. Authors agree that this article remains permanently open access under the terms of the Creative Commons Attribution License 4.0 International License

\begin{abstract}
Indonesia is a disaster-prone country and has a large population, as evidenced by the increasing number of disasters almost every year. In Aceh province, the second earthquake occurred on 7 December 2016 Wednesday, in the area of Pidie Jaya Regency. This earthquake has caused many deaths and injuries, and damage to buildings. The victims died and were injured mainly due to collapsed residential buildings and other damaged public buildings. The methodology used in this research is by observing and measuring both quantitative and qualitative in the field and then analyzed based on the components of government regulations. The first qualitative measurement uses a map digitization checklist prepared, then the field survey to take pictures and quantitative inspection based on the type of building, building level, and building construction elements. Finally, analyzing the data uses the building regulation component of the government. The results showed that the earthquake that occurred resulted in almost all buildings with modern structures suffered minor damage. The rest sustained small loss and severe damage (collapsing). All buildings with modern structures consist mostly of structural elements/materials that are not under government regulations. This study also found that there are still residential buildings with traditional structures not damaged by the earthquake. This finding is expected to provide public awareness that constructing settlements with modern structures must use structural elements and
\end{abstract}

components under building regulations from the government.

Keywords Rapid Assessment, Risk Assessment, Building Construction, Earthquake Area, Seismic Damage

\section{Introduction}

The earthquake that occurred on Wednesday, 7 December 2016, at around 05:03 WIB, centered in the Meureudu Pidie Jaya region, Aceh, Indonesia, with a magnitude of 6.5 on the Richter Scale (SR), was a strike-slip earthquake. The earthquake is located in the sea adjacent to the Samalanga Fault but slightly to the west. Based on the earthquake mechanism, the strike direction of the quake is expected to head northwest. From the map of the earth's surface elevation model, it can see that there is a fault near the Samalanga Fault, and it seems that the earthquake is located along the fault. An earthquake with a magnitude of 6.5 on the Richter Scale (SR) that has rocked Pidie Jaya region resulted in not a few fatalities (both minor injuries to the death toll), also damaged buildings and other public facilities that slightly damaged to the point of collapse [1], [2].

This earthquake did not cause a tsunami because it centered on land and its strength was not strong enough to 
generate changes in the seabed that could trigger a tsunami. However, it caused damage and losses to residential buildings and public facilities such as mosques and regional public hospitals [3], [4]. It also resulted in a break in the road section, and the flow of electricity to Pidie Jaya cut off. However, damage and loss of residential buildings and public facilities such as mosques and public hospitals are severely damaged. It also resulted in cracks in the road, and electric flow to Pidie Jaya disconnected [1], [2].

Most collapsed buildings are multi-story buildings. And there are several public facility buildings such as school buildings, colleges, mosques, shop houses (shop houses) and markets and health facilities such as hospitals [1]-[3], [5], [6]. The community settlement buildings also damaged, including most of the one-story settlements [5], [7]-[10]. Based on the level of damage in each region, which suffered a substantial loss in was Trieng Gading sub-district, Pidie Jaya, this area was the closest area to the earthquake [3], [7], [11]-[13]. Damage occurs in the region need to check based on the extent of damage to the building. And the type of damage to [12], [14]-[17].

The inspection needs to be done visually on the components of the building structure, building architecture, and utilities as a whole [7], [12]. The investigation was also carried out simultaneously with the assessment of damage to buildings, which focused on the evaluation of loss to public buildings such as schools and mosques, then the assessment of loss damage to buildings owned by residents (houses, shophouses, etc.) within the area [1][7], [11], [12], [18]. The purpose of this study finds the pattern of the level of damage to buildings due to the earthquake [1], [3]. And formulate proposals and recommendations for the future how to build earthquake-resistant buildings for the community and local government [5], [19], [20]. There was a lot of damage to people's buildings that occurred after the earthquake. The damage is distinguished by type, namely minor damage, moderate damage, and severe damage. Below are some examples of structural component damage types.

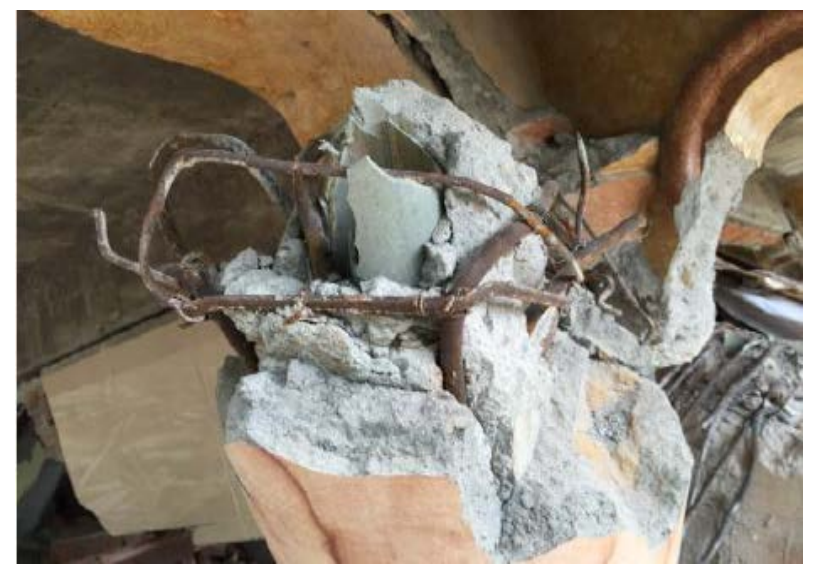

Figure 1. Moderately damage, planting pipes for the disposal of water located in the building column

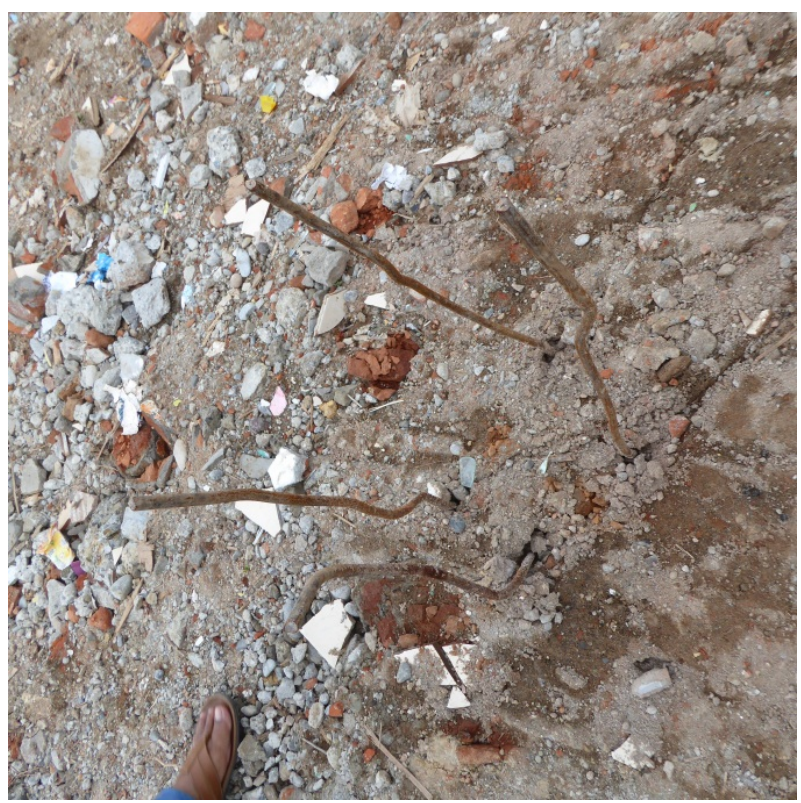

Figure 2. Heavily damage, use of column frame iron with a size that does not comply with regulatory standards

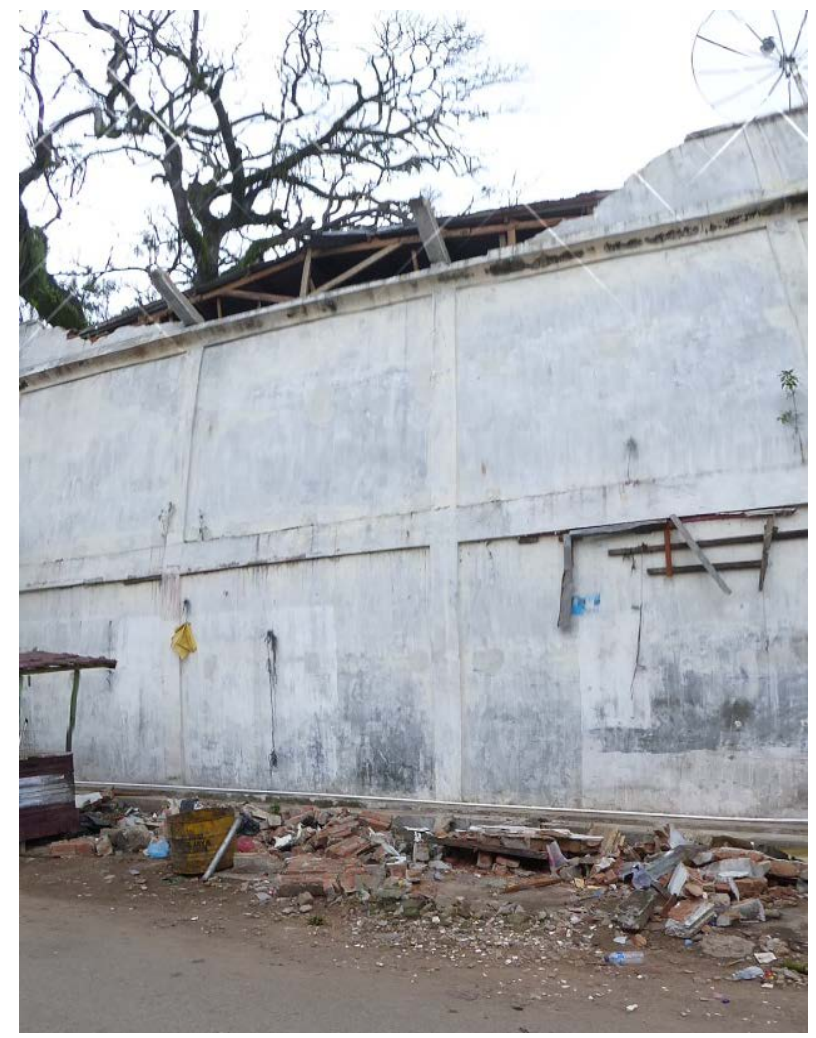

Figure 3. Mildly damaged, crumbling building walls that are not reinforced by the frame

Indonesia already has regulations and guidelines for making earthquake-resistant buildings; there are also technical guidelines for earthquake resistant buildings that can be used by the community. Those regulations and guidelines have been used by people to build buildings that use modern structures and materials [18]. However, there are still people who use traditional structures and materials 
in a building, such as a case study of traditional buildings in Bali [21]. The following are the basic principles of earthquake-resistant building planning [22], [23]:

1. Floor plan or house building should be simple in shape, symmetrical to both building axes, and not long. A fair comparison between the width of the building with the building length is 1:2,

2. If there is a floor plan or house building that is not symmetrical, then the floor plan must be separated or by dilatation with the separation line so that it is a floor plan that is still a series of the unity of the symmetrical layout,

3. Placement of insulating walls and door/window pits must be as balanced as possible to the building plan axes,

4. Fields of walls should form closed boxes,

5. The roof is as light as possible,

6. It would be nice if the foundation soil is dry, dense, and evenly distributed. The base of the foundation should lie deeper than $45 \mathrm{~cm}$ below the surface of the original ground,

7. The foundation should be made continuously around the building without interruption. The foundation of the partition walls is also made consistently. If the foundation consists of river rock, it is necessary to install a binder/beam along the foundation,

8. Local foundations need to fasten to one another using foundation beams,

9. For the location, if the building or house will build on the hilly land, then the hillside side should be selected a stable so as not to get landslides during earthquakes to occur quickly,

10. If the building or house that will build on the ground, then not allowed to be made in a location that has a type of soil that is very fine and sensitive clay (ground inflated),

11. Structure of buildings or houses should be designed in such a way that has: good ductility (material and construction); flexibility of installation; and has the durability of natural and artificial damages,

12. Roof frames for building or earthquake-resistant houses advised wearing nail board material. The roof frame is exceptionally lightweight, and its craftsmanship is pure. Wood size used $2 \mathrm{~cm} \times 10 \mathrm{~cm}$, and the number of nails used a minimum of 4 pieces of nails with a length of 2.5 times thick wood [21].

\section{Materials and Methods}

The methodology used in this research is quantitative and qualitative field observations. Qualitative measurements using a checklist of digitization maps prepared from the beginning, a field survey in taking pictures and photo documents. Quantitative inspection, namely; building measurements, building structure components, and building elements.

The location of the research is on the coast near the epicenter. And with the number of buildings in the area studied in this study as many as 354 structures [1], [2], [24]. In determining the level of damage to buildings, the most common method instruments are to assess the level of damage based on weighting, which is based on government building regulations [25].

This weight could be used as the basis for determining the priority scale in the condition of building damage to the earthquake using visual and rapid assessment patterns. Building damage was reviewed through visualization inspection and image capture using a camera. In this analysis method, the data found is then categorized into 4 (four) parts, namely the category of building functions, the building floor height, the building damage (light, medium, heavy), and the category of heritage buildings (over 50 years old).

\section{Result and Conclusion}

This study's results are in the form of findings that explain the pattern of building damage in the study area. These findings categorized into four parts :

1. Categories of building functions, in the area, found various kinds of building functions such as residential buildings, commerce, 2-story shophouses, mosques, and offices;

2. Categories of building heights, in the area, found various kinds of building heights ranging from one floor, two floors and three floors (highest height);

3. Category of building damage, in the area found the building loss that is mildly damaged buildings, moderately damaged buildings, and heavily damaged buildings;

4. The category of heritage buildings, where the definition of heritage buildings here are buildings over 50 (fifty) years old.

The picture below is the result of a survey based on the above category. 


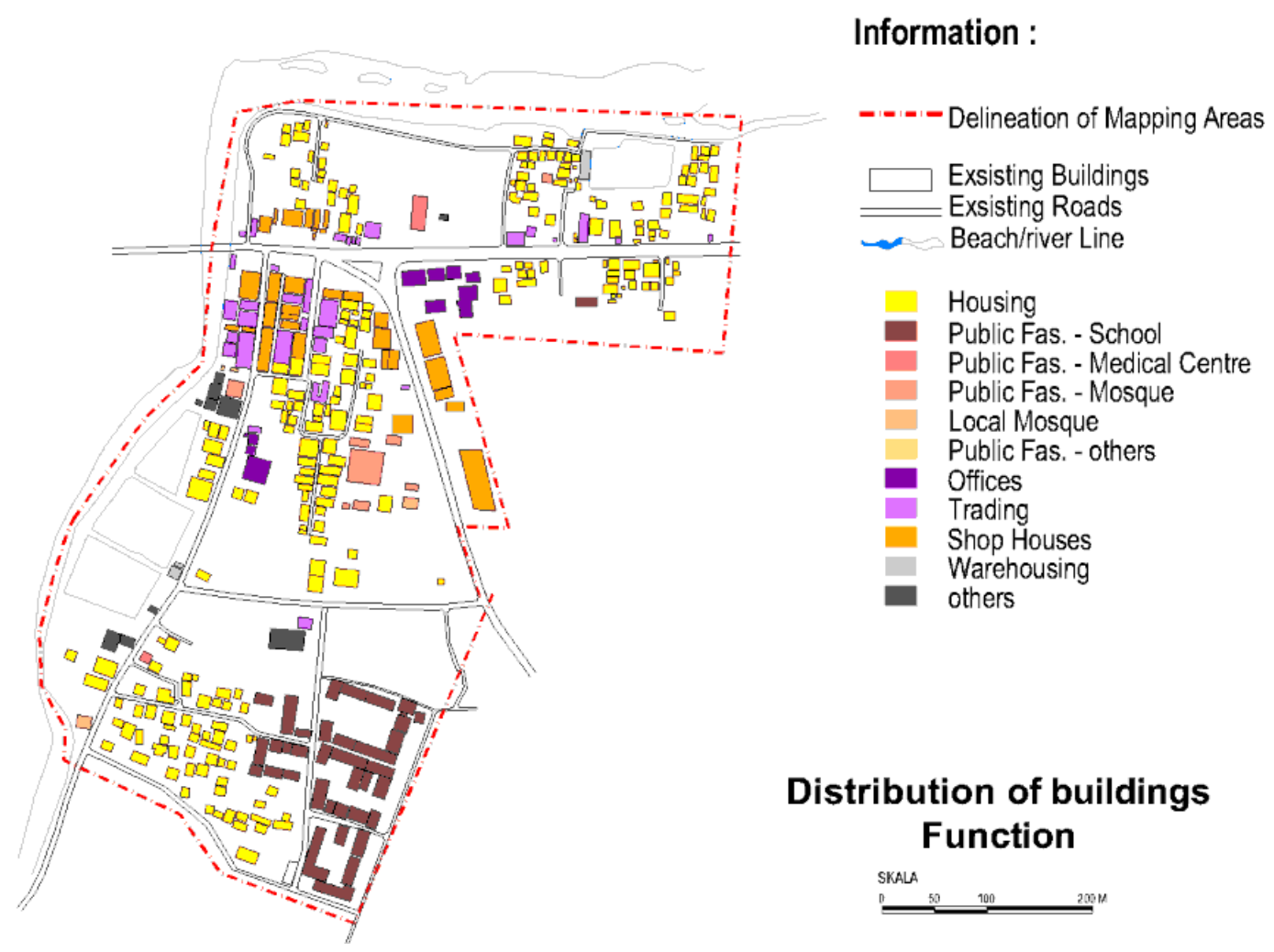

Figure 4. Buildings Function

In the picture above, it appears that the building functions analyzed in the area are mostly settlements. Then, function building public facilities such as schools, commercial and shophouses, and worship buildings [25].

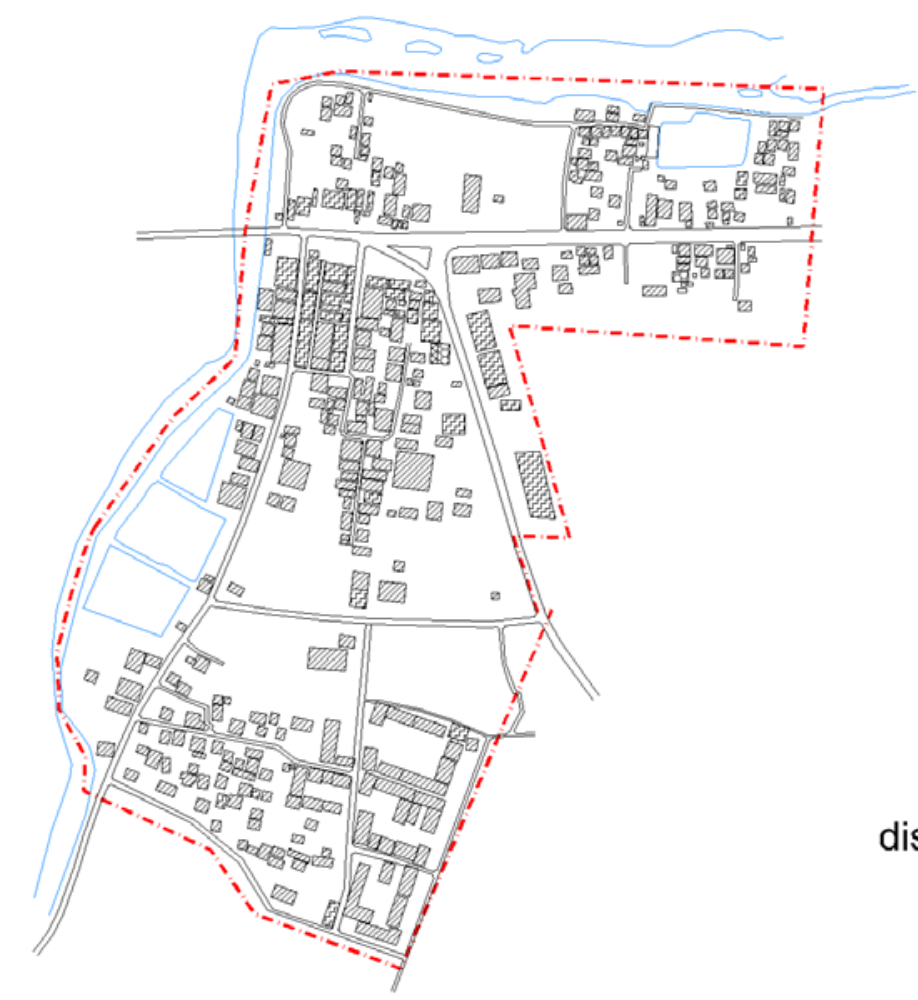

\section{Information :}

- - - - Delineation of Mapping Areas

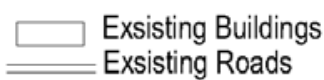

Beach/river Line

27l floor

झझ 2 floor

3 floor

푸영 $>3$ floor

distribution of buildings

SKALA

Height

Figure 5. Buildings Height 
The picture above maps the height of the building in the area. Most are 1-story buildings for settlements, and the rest are shop houses and trade or office buildings. The maximum height is three floors, and only 1 and 2 buildings are owned [24], [26], [27].

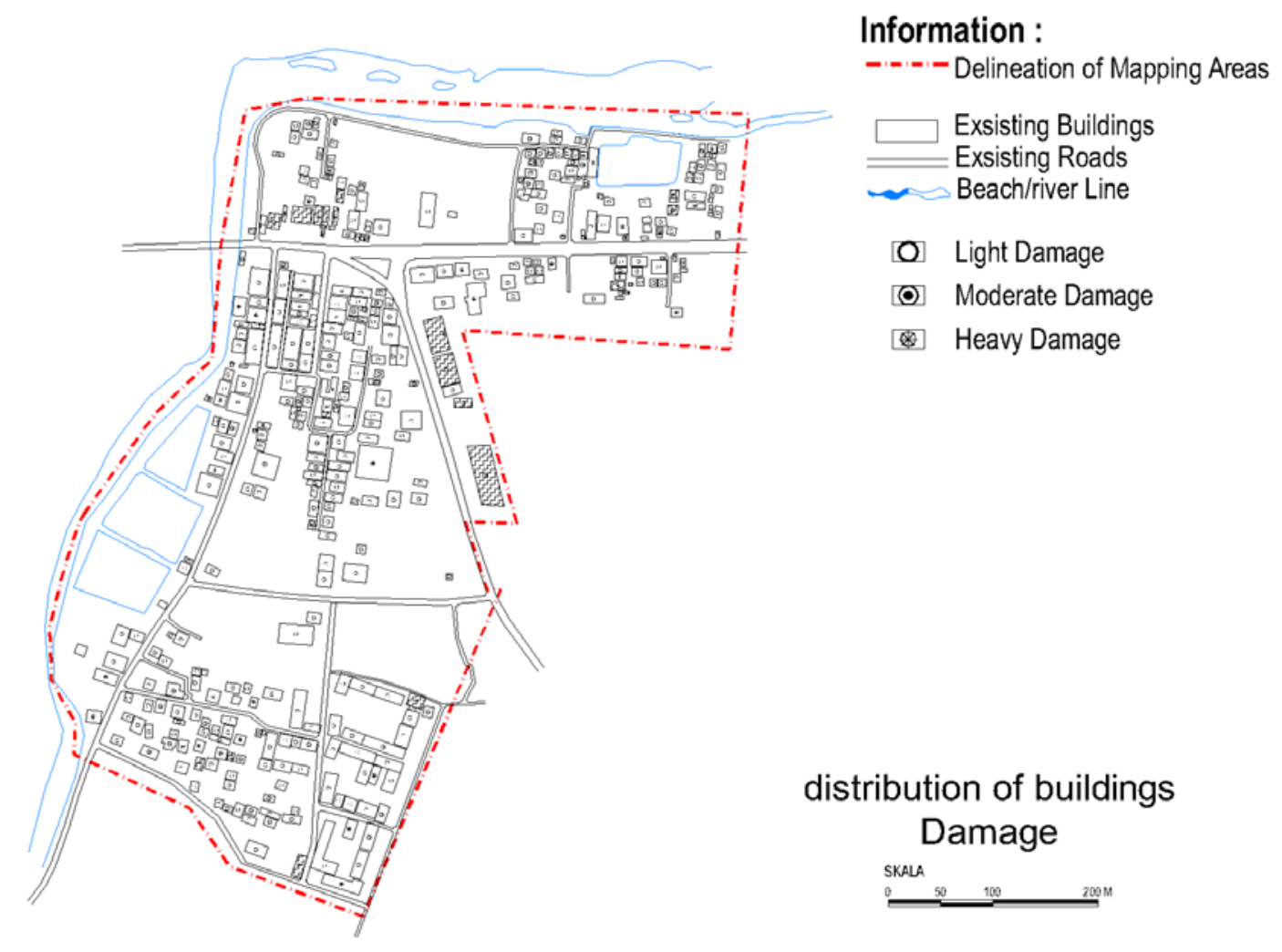

Figure 6. Buildings Damaged

The picture above maps the category of building damage, divided into minor loss, moderate loss, and massive loss. The result is that most of the 1st-floor buildings with settlement functions suffer minor damage. While the 2nd and 3rd-floor buildings with shop and trade functions only experienced moderate loss and only a few buildings. The majority of minor damage to residential structures do not meet government earthquake-resistant building regulations [28]-[30]. 


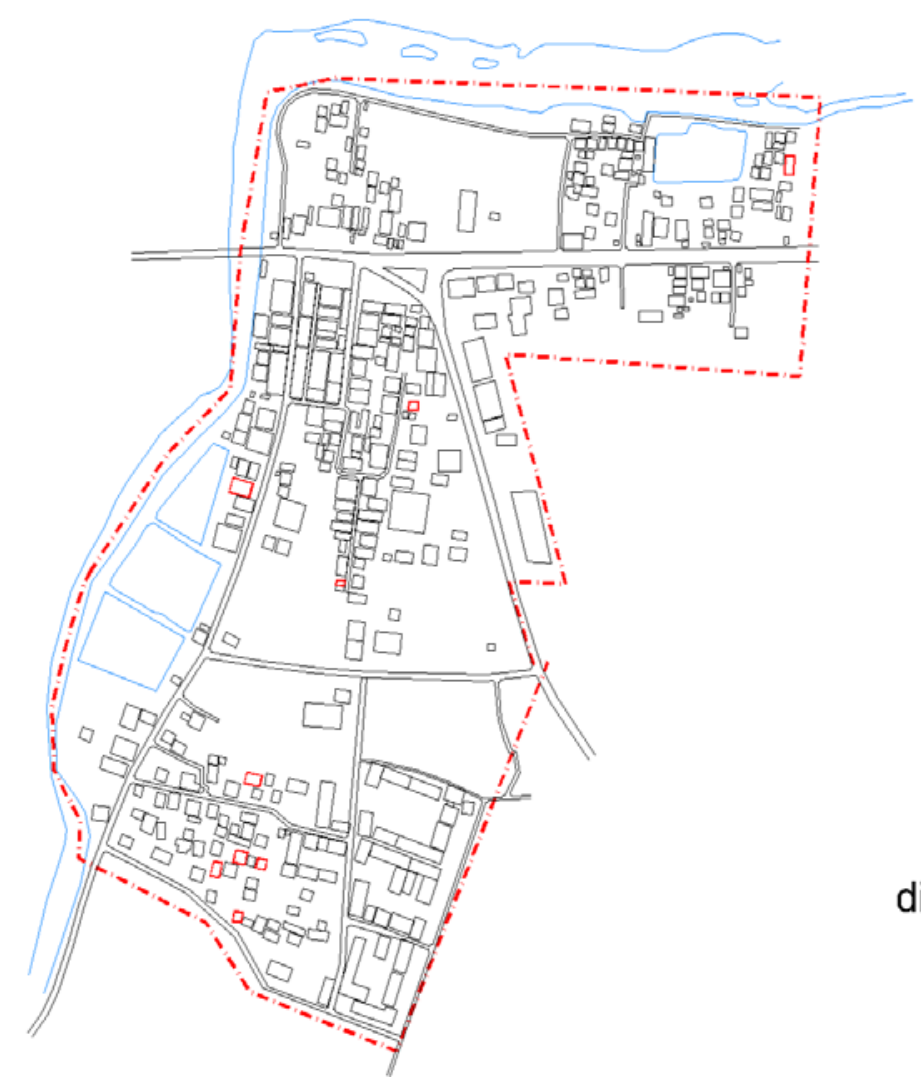

\section{Information :}

-----Delineation of Mapping Areas

\section{Exsisting Buildings}

Exsisting Roads

Beach/river Line

Heritage Building

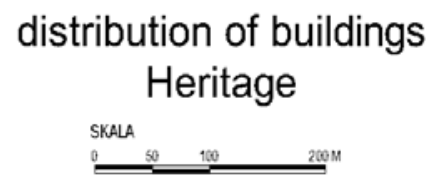

Figure 7. Heritage buildings

The picture above is a mapping of heritage buildings with age above 50 years. It found that the earthquake did not damage heritage buildings with traditional structures (wood and bamboo). Those 9 (nine) heritage building is a one-story residential building. This finding is a further question of why buildings with traditional structures can withstand the earthquake [22], [31].

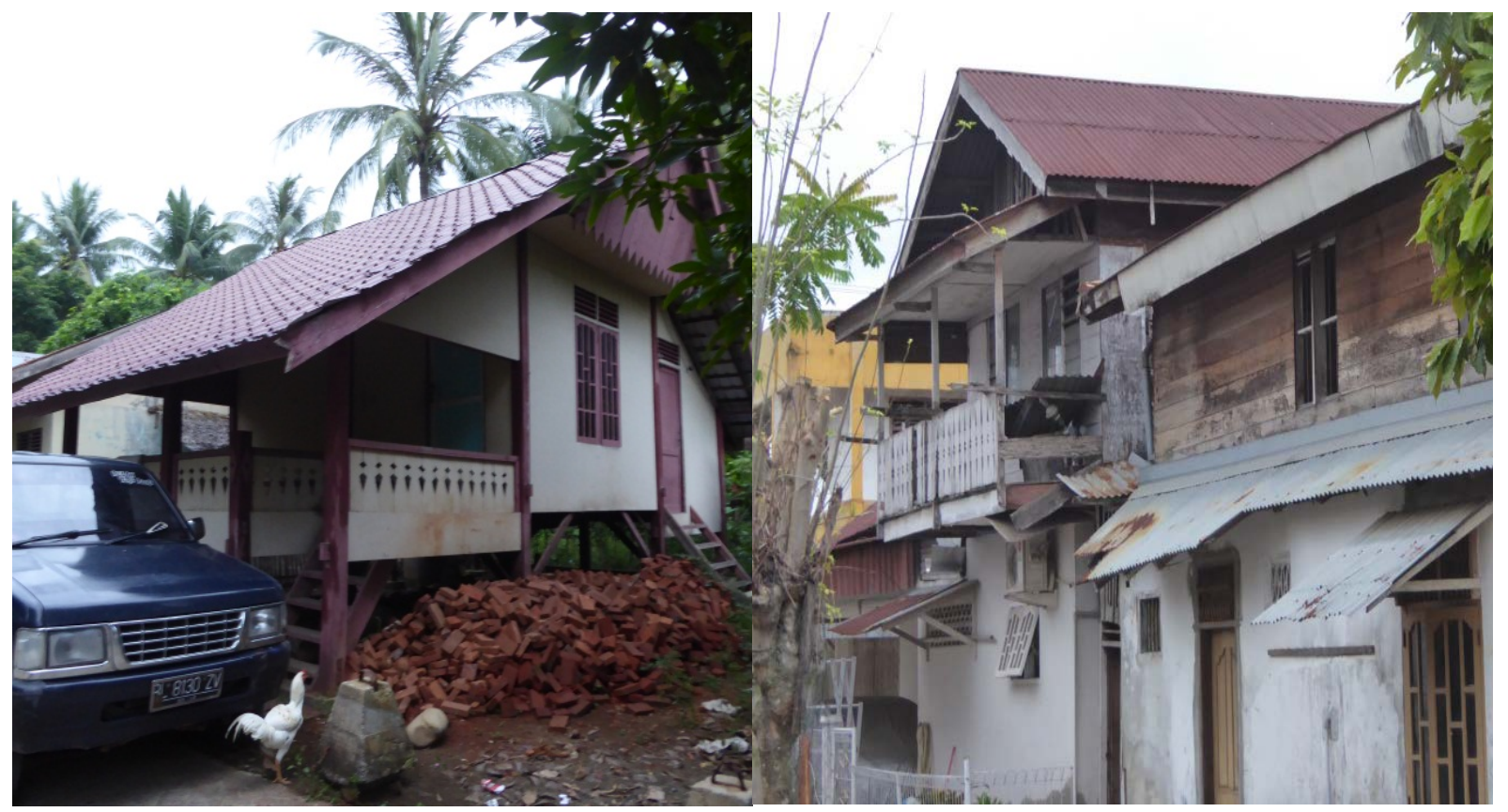

Figure 8. Heritage buildings 
The results of the above study can be summarized more clearly in the table below.

Table 1. Data Analysis, 2020

\begin{tabular}{|c|c|c|c|c|}
\hline \multirow{2}{*}{ Variable } & \multicolumn{4}{|c|}{ Category (building) } \\
\cline { 2 - 5 } & $\begin{array}{c}\text { Damag } \\
\text { e }\end{array}$ & height & Function & Heritage \\
\hline Low & 317 & $\begin{array}{c}2781, \\
392\end{array}$ & residential & 9 \\
\hline Moderate & 28 & $\begin{array}{c}241,32, \\
13\end{array}$ & Commerce,etc & - \\
\hline Massive & 29 & 281,12 & Public facilities & - \\
\hline Total & \multicolumn{4}{|c|}{374 buildings damaged } \\
\hline
\end{tabular}

$x^{1}$ (one floor), $x^{2}$ (two floors), $x^{3}$ (third floors).

\section{Conclusion}

An earthquake that occurred in Pidie Jaya on 7 December 2016 has been carried out with identification and research in building functions, buildings' height, damage to buildings, and heritage buildings with age above 50 years old. The results of the study are:

1. Most of the buildings that suffered minor loss are residential function buildings with a building height of 1 floor (278 buildings),

2. The height of the building two levels and three levels with shop and trade functions suffered moderate damage and massive damage,

3. Found supporting material on buildings' structure exposed to the earthquake that does not conform to the government's standard building regulations, thereby affecting the building's damage level. Need further research.

4. Buildings that have experienced average loss are buildings with modern structures that built without using government regulations [22], [31], there needs to be further research,

5. Found a building with traditional fabrics (wood and bamboo) which undamaged at all due to the earthquake; there needs to be new research,

6. As a result of the earthquake that occurred turned out to make the most of minor damage to residential buildings that do not meet earthquake-resistant building regulations from the government,

7. The proposal idea to socialize to the community that development without following local government building regulations is hazardous to the safety of building users,

8. Another proposal is that local authorities regularly conduct earthquake-resistant home training for builders,

9. Supervision of the construction of public buildings owned or managed by the community (self-managed),
10. In the future, hopes that this research can provide insight to the public that the importance of earthquake-resistant building guidelines from the government,

11. Recommendations for the future: There needs to be further research on buildings' damage due to the Pidie Jaya region earthquake. Then further investigation on heritage buildings with traditional structures in the area that was not damaged.

\section{Acknowledgments}

The authors would like to thank LPPM and AJIB in the Universitas PGRI Yogyakarta for providing support to publish this paper and for the KARTAGAMA in Indonesia who support this research data.

\section{REFERENCES}

[1] Tim PusGen, Kajian Gempa Pidie Jaya Provinsi Aceh Indonesia, vol. 24, no. 3. 2008.

[2] UNSYIAH, "Hasil-Kaji-Cepat-Unsyiah-Gempa-Pijay-07-Des-2016," 1389.

[3] M. Syifa, P. R. Kadavi, and C. W. Lee, “An artificial intelligence application for post-earthquake damage mapping in Palu, central Sulawesi, Indonesia," Sensors (Switzerland), vol. 19, no. 3, Feb. 2019.

[4] A. Mishra, R. Ghate, A. Maharjan, J. Gurung, G. Pathak, and A. N. Upraity, "Building ex ante resilience of disaster-exposed mountain communities: Drawing insights from the Nepal earthquake recovery,” Int. J. Disaster Risk Reduct., vol. 22, no. March 2017, pp. 167-178, 2017.

[5] R. P. Nanda and D. R. Majhi, "Rapid seismic vulnerability assessment of building stocks for developing countries," KSCE J. Civ. Eng., vol. 18, no. 7, 2014.

[6] A. N. Martins, C. Forbes, A. A. Pereira, and D. Matos, “The changing city: Risk and built heritage. the case of Lisbon downtown," in Procedia Engineering, 2018, vol. 212, pp. 921-928.

[7] S. K. Jain, "Earthquake safety in India: achievements, challenges and opportunities,” Bull. Earthq. Eng., vol. 14, no. 5, pp. 1337-1436, May 2016.

[8] Y. N. Yen, C. F. Cheng, and H. M. Cheng, "Disaster risk management and measurement indicators for cultural heritage in Taiwan," in ISPRS Annals of the Photogrammetry, Remote Sensing and Spatial Information Sciences, 2015, vol. 2, no. 5W3, pp. 383-388.

[9] D. Hermon, Ganefri, Erianjoni, I. Dewata, P. Iskarni, and A. Syam, "A policy model of adaptation mitigation and social risks the volcano eruption disaster of sinabung in Karo regenCY - Indonesia,” Int. J. GEOMATE, vol. 17, no. 60, pp. 190-196, 2019. 
[10] D. Hermon, Ganefri, Erianjoni, I. Dewata, P. Iskarni, and A. Syam, "A policy model of adaptation mitigation and social risks the volcano eruption disaster of sinabung in Karo regenCY - Indonesia,” Int. J. GEOMATE, vol. 17, no. 60, 2019.

[11] I. Takewaki, “Toward greater building earthquake resilience using concept of critical excitation: A review,” Sustainable Cities and Society, vol. 9. pp. 39-53, Dec-2013.

[12] S. Xie et al., "Crowdsourcing rapid assessment of collapsed buildings early after the earthquake based on aerial remote sensing image: A case study of Yushu earthquake,” Remote Sens., vol. 8, no. 9, 2016.

[13] L. Moya, E. Mas, S. Koshimura, and F. Yamazaki, "Synthetic building damage scenarios using empirical fragility functions: A case study of the 2016 Kumamoto earthquake,” Int. J. Disaster Risk Reduct., vol. 31, pp. 7684, Oct. 2018.

[14] V. Pica, "Beyond the Sendai framework for disaster risk reduction: Vulnerability reduction as a challenge involving historical and traditional buildings,” Buildings, vol. 8, no. 4, Mar. 2018.

[15] S. A. Allali, M. Abed, and A. Mebarki, "Post-earthquake assessment of buildings damage using fuzzy logic,” Eng. Struct., vol. 166, pp. 117-127, Jul. 2018.

[16] O. Kaplan, Y. Guney, A. Topcu, and Y. Ozcelikors, “A rapid seismic safety assessment method for mid-rise reinforced concrete buildings,” Bull. Earthq. Eng., vol. 16, no. 2, 2018.

[17] M. Y. H. Bangash, “Earthquake Resistant Buildings,” Earthq. Resist. Build., vol. 7, no. 10, pp. 921-928, 2011.

[18] R. K. Sirigiri, K. B. G. Krishna, B. Ravali, and V. S. Pothuri, "COMPARITIVE STUDY ON PERFORMANCE OF TALL,” vol. 7, no. 18, pp. 235-243, 2020.

[19] P. Berke, G. Smith, and W. Lyles, "Planning for resiliency: Evaluation of state hazard mitigation plans under the disaster mitigation act," Natural Hazards Review, vol. 13, no. 2. 2012.

[20] K. Kojima, K. Fujita, and I. Takewaki, "Building earthquake resilience in sustainable cities in terms of input energy," Sustainable Cities and Society, vol. 12. Elsevier Ltd, pp.
46-62, 2014.

[21] N. K. A. Dwijendra, "Meru as a Hindu sacred building architecture with a high roof and resistant to earthquakes in Bali, Indonesia,” Civ. Eng. Archit., vol. 8, no. 3, pp. 350358, 2020.

[22] S. Keputusan et al., "Pedoman pembangunan bangunan tahan gempa,” no. September, 1993.

[23] K. Pengantar, Manual Perbaikan Bangunan Sederhana Yang Rusak Akibat Gempa Bumi, Boen, Teddy, 1992. 2005.

[24] H. Syahputra, "Indigenous knowledge representation in mitigation process: a study of communities' understandings of natural disasters in Aceh Province, Indonesia,” Collect. Curation, vol. 38, no. 4, pp. 94-102, Sep. 2019.

[25] National Disaster Management Agency of Republik Indonesia, "Regulation of the Head of National Disaster Management Agency of the Republic of Indonesia Number 3 Year 2011 on Standardization of Disaster Database," 2011.

[26] O. R. Danar and D. Pushpalal, "Building Community Resilience: Conceptual Framework and its Application in Post Tsunami Resettlement,” Procedia Econ. Financ., vol. 18, no. September pp. 489-496, 2014.

[27] R. Jena et al., "Integrated model for earthquake risk assessment using neural network and analytic hierarchy process: Aceh province, Indonesia,” Geosci. Front., vol. 11, no. 2, pp. 613-634, 2020.

[28] O. R. Danar and D. Pushpalal, "Building Community Resilience: Conceptual Framework and its Application in Post Tsunami Resettlement,” Procedia Econ. Financ., 2014.

[29] E. Irwansyah and S. Hartati, “As ssessmen nt of Bu uilding Damage Caused b Earth by hquake : Integrat tion of FN NN and GIS,” IERI Procedia, vol. 10, pp. 196-202, 2014.

[30] R. Afrian, J. Hariadi, B. Akob, and Z. R. Islami, "Local Culture Inventory for Disaster Mitigation Learning,” IOP Conf. Ser. Earth Environ. Sci., vol. 412, no. 1, 2020.

[31] S. Das and P. Mukhopadhyay, "Multi-hazard disaster resilient housing with bamboo-based system," Procedia Eng., vol. 212, pp. 937-945, 2018. 